ЗАИКИН Андрей Анатольевич - аспирант Северо-Западного института управления - филиала Российской академии народного хозяйства и государственной службы при Президенте РФ (199178, Россия, г. Санкт-Петербург, В.О., Средний np-кт, 57/43; Sptk2011@yandex.ru); советник председателя Законодательного собрания Санкт-Петербурга

ВОЛКОВ Виталий Александрович - доктор политических наук, профессор; профессор СанктПетербургского государственного университета (199034, Россия, г. Санкт-Петербург, Университетская наб., 7-9; vitv@rambler.ru)

\title{
ИСТОРИЧЕСКИЕ И ЛОГИЧЕСКИЕ ОСНОВАНИЯ СТРУКТУРЫ ПОНЯТИЯ ПОЛИТИЧЕСКОЙ БОРЬБЫ
}

Аннотация. В статье рассматривается феномен политической борьбы в историческом и логическом измерении. Начиная с Античности, политическая борьба развивается в различных формах, но не становится предметом понятийного анализа. Авторы придерживаются точки зрения, что понятие политической борьбы не исчерпывается понятием политического конфликта. Оно включает в себя три необходимых элемента: определение целей и пропаганду, собственно конфликт, достижение властного статуса. Предлагается авторское определение политической борьбы.

Ключевые слова: политическая борьба, пропаганда, конфликт, риторика, выборы, классовая борьба, публичность, властный статус

$\Pi$ редставление о политике неразрывно связано с представлением о политической борьбе. Видимо, в связи с этим политическая борьба крайне редко становится предметом политического исследования. О феномене политической борьбы говорят всегда, но ее определение, сущность и содержание уходят на второй план. Философия была более внимательна к рассматриваемому понятию. Уже в античной философии, начиная с Гераклита, борьба становится фундаментальным понятием, характеристикой движения, связанной с изменчивостью и противоречивостью мира. Борьба является источником изменений и характеризует как противоречивость, так и целостность процессов. Борьба у древних греков понимается не как столкновение противоборствующих субъектов, а как раздвоение единого и борьба сторон этого единого.

Античное мировоззрение проецировало космос на социальную жизнь, и наоборот, социальную жизнь - на космос. Вследствие этого вся мудрость метафизики касалась жизни полиса. Борьба как философская категория была ключом и к политической борьбе.

Одним из фундаментальных политических принципов античного мира была борьба с варварами. Восточные царства несли деспотию и рабство. Греки понимали свободу не только как независимость, но и как господство человека над своими страстями. Вследствие этого войны с варварами были войнами с рабами по природе и отражали естественный ход борьбы в мироздании. Войны носили цивилизационный характер, и их прямым результатом был приток рабов. Это отражалось и на внутриполитической сфере. Рабство несло внутреннюю угрозу греческим государствам как источник восстаний, а также как возможность для грека утратить свободу из-за кабальных обязательств.

Политическую борьбу Аристотель характеризовал как распри, раздоры между аристократией и народом, который в этой борьбе постепенно расширял свои права. Демос, верхушкой которого были богатые купцы и мореплаватели, противопоставлял аристократии крови аристократию духа, тем самым расширяя 
базу имеющих право на власть. Итогом этой политической борьбы стал век демократии.

Демократия как форма правления подразумевает наличие таких институтов власти, как народное собрание, совет пятисот, народный суд присяжных. Все эти институты предполагают состязательность различных точек зрения на политику и законы с соответствующей аргументацией. Борьба за интересы демоса или аристократии принимает уже иные формы, отличные от вооруженной борьбы. Победа в народном собрании обеспечивалась поддержкой демоса. Такие крупные реформаторы, как Клисфен, побеждали своих конкурентов, находя поддержку у народа. «После низвержения тирании началась распря между Исагором, сыном Тисандра, другом тиранов, и Клисфеном, происходившим из рода Алкмеонидов. Побеждаемый гетериями, Клисфен привлек на свою сторону народ, обещая предоставить народной массе политические права» [Аристотель 2007]. Социальная политика была мощным инструментом политической борьбы.

Не менее важной формой политической борьбы в греческом обществе было установление новых законов. Наиболее ярким примером является принятие Периклом в 450 г. до н.э. закона о гражданстве, согласно которому гражданами считались только те, у кого и отец, и мать являлись гражданами Афин. Этот закон был направлен против широких слоев аристократии, у которых было принято брать жен в других государствах, тем самым расширяя свои связи и влияние. Знать других городов была, таким образом, материальным ресурсом для аристократических партий, что представляло опасность для афинской демократии. Таким образом, составление родословной становится политически значимым делом. Обвинение в иноземном происхождении могло быть равносильно обвинению в государственной измене.

Демократическая форма правления стала источником такой формы политической борьбы, как риторика. В борьбе за умы демоса искусство убеждения выросло в значительную отрасль знания. Главенствующее место в общественной жизни греков начинает занимать образование, мастерство публичных выступлений, владение словом. Слово становится основным инструментом политической жизни в деле завоевания поддержки демоса. «Сила слова начинает преобладать над другими орудиями власти» [Плутарх 1994]. Необычайная популярность Перикла как государственного деятеля связывалась не только с его реформами, но и ярким даром красноречия, которым он обладал. Особую роль в политической борьбе играли не только политические деятели, но и ораторы, которые могли создать образ политического деятеля, прославляли его деяния. Искусство ораторов состояло в создании как положительных, так и отрицательных образов, которые не всегда соответствовали действительности.

Из риторики вырастают манипулятивные формы политической борьбы. Одной из таких форм являлось создание «образа врага» как некой тайной силы. Часто формировались такие образы, как «предатель», «друг тирана», «враги демократии». Эти образы наполнялись эмоциональными негативными характеристиками, а затем привязывались к тем или иным политикам.

Политическая история Древнего Рима не сильно изменила общую картину форм политической борьбы. Древний Рим, как отмечал еще Полибий, имел свои особенности в государственном устройстве, которые обусловила его история. Одним из важнейших государственных органов, представлявшим интересы патрициев, был сенат, созданный из представителей аристократических семей еще в царский период истории Рима. Существует мнение, что первоначально это был выборный орган. «Напомним, что римский сенат <... был, без 
сомнения, избираемым органом, пока его члены - главы немногих знатных фамилий, утвердивших свое преобладание, не добились для себя и своих наследников права состоять в сенате независимо от народного выбора» [Кальгина, Белоновский 2015]. Сенат был местом, в котором сталкивались интересы магистратов, исполняющих различные государственные должности, и народного собрания. Решения сената вырабатывались в результате прений ораторов. Поскольку сенат состоял из нобилитета, большая часть решений принималась единодушно.

Выборность государственных должностей создавала обширные возможности для политической борьбы. «Главные магистраты, консулы, а затем и большинство других (цензоры, эдилы и квесторы) были выборными... Напротив, сенат формально оставался консультативным органом при магистратах, основной функцией которого оставался consilium, а его реальное полновластие явилось результатом экстралегальных факторов, огромного авторитета, а отчасти и правовой узурпации» [Егоров 2009: 44].

История античного мира продемонстрировала достаточно широкое многообразие форм политической борьбы. На фоне политического насилия в виде войн, восстаний рабов, заговоров и переворотов были сформированы ненасильственные формы политической борьбы, такие как политические дискуссии в народном собрании, издание законов, риторика, политическая манипуляция, остракизм. Эти ненасильственные формы политической борьбы стали основой политической культуры последующих эпох и поколений.

Вместе с тем политические философы античности не делали понятие политической борьбы предметом рассмотрения. Сущность и природа политической борьбы не стали предметом анализа.

Эпоха Средневековья, несмотря на достаточное число форм политической борьбы (восстания крестьян, борьба за власть между церковью и государством и др.), также не дала примеров анализа понятия политической борьбы.

В Новое время английский философ Томас Гоббс в своем знаменитом произведении «Левиафан» поставил понятие «войны всех против всех» в основу характеристики естественного состояния человека. Источником такого состояния является инстинкт самосохранения. Общественный договор, создающий государство, прекращал это состояние.

Внимание ученых политическая борьба привлекла уже только в начале XIX в., когда французский историк Ф. Гизо объяснил историю Франции как результат борьбы между аристократией и третьим сословием [Гизо 2007]. Феномен классовой борьбы объяснялся, исходя из завоевательной теории происхождения государства. Политические причины сформировали экономический конфликт классов.

Эта точка зрения, широко распространенная в кругах французских историков, была подвергнута основательной критике К. Марксом и Ф. Энгельсом. «Если на первый взгляд происхождение крупного, некогда феодального землевладения могло еще быть приписано, по крайней мере в первую очередь, политическим причинам, насильственному захвату, то по отношению к буржуазии и пролетариату это было уже немыслимо. Слишком очевидно было, что происхождение и развитие этих двух больших классов определялось чисто экономическими причинами. И столь же очевидно было, что борьба между крупными землевладельцами и буржуазией, так же, как и борьба между буржуазией и пролетариатом, велась прежде всего ради экономических интересов, для осуществления которых политическая власть должна была служить всего лишь средством» [Энгельс 1955: 308].

В «Манифесте коммунистической партии» указывается, что вся предшеству- 
ющая история является историей борьбы классов. Борьба становится в центре внимания революционных движений и политических партий. Марксисты различают такие виды борьбы, как экономическая, политическая, идейная.

Возникшая в конце XIX в. конфликтология рассматривает Маркса как своего предшественника. Один из основоположников конфликтологии Георг Зиммель (1858-1918) рассматривал общество не как органическое единство, а как совокупность индивидов, связанных интеракцией, содержанием которой является борьба. «У человека действительно есть формальное влечение враждебности как парная противоположность потребности в симпатии... Исторически оно берет начало в одном из тех психических процессов дистилляции, когда внутренние движения в конце концов оставляют в душе после себя общую им форму как некое самостоятельное влечение. Интересы различного рода столь часто побуждают к борьбе за определенные блага, к оппозиции определенным личностям, что, вполне вероятно, в качестве остатка в наследственный инвентарь нашего рода могло перейти состояние возбуждения, само по себе побуждающее к антагонистическим выражениям» [Зиммель 1996: 503].

Конфликтологи предложили множество определений конфликта и теорий конфликта. Один из классиков конфликтологии Льюис Коузер предложил следующее определение: «Конфликт есть борьба за ценности, власть или ресурсы, недостаток которых ощущается, в каковой борьбе мера успеха определяется мерой воздействия, причиненного вреда или уничтожения соперника» [Козер 2000].

Российский социолог А. Здравомыслов предлагает следующее определение политического конфликта: «политический конфликт есть постоянно действующая форма борьбы за власть в данном конкретном обществе» [Здравомыслов 1995: 259].

В конфликтологии очень часто конфликт объясняется через родовое понятие «борьба». Отсюда следует, что понятие политической борьбы шире понятия политического конфликта.

В свою очередь, в словарях и энциклопедиях даются разные варианты определений, например, «политическая борьба (political struggle) - состязание, соперничество, схватка в политической жизни и деятельности противостоящих друг другу лиц, сил, партий, движений, отстаивающих свои политические взгляды, позиции и устремления» 1 .

К сожалению, в современной литературе почти нет работ, посвященных собственно политической борьбе. Среди существующих работ интерес представляет монография «Политическая борьба в современных условиях» [Борщ 2011]. Борщ А.А. предлагает следующее определение: «Автор под политической борьбой понимает сложное общественно-политическое явление, направленное на переход (завоевание) власти определенной политической группировки (классом) в интересах достижения определенных политических, экономических, военных и других интересов» [Борщ 2013: 70]. В своей работе он выделяет такие формы политической борьбы, как парламентская деятельность, революционная борьба, партизанское движение.

Чарльз Тилли также выделяет несколько форм политической борьбы: это революции, завоевания, конфронтации и колонизация [Tilly 2004].

В своей работе «Психология политической борьбы» А.М. Зимичев рассматривает цели политической борьбы, которые предполагают несколько вариантов: один из участников борьбы может победить, может сорвать противодействие противника, может не дать победить противнику, не достигнув цели самому

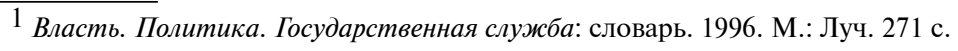


[Зимичев 1993: 75]. Достижению цели способствуют шестнадцать методов политической борьбы.

Известный конфликтолог Д. Зеркин рассматривает структуру политической борьбы. «Для анализа структуры политической борьбы можно предложить следуюшую схему:

- субъект - агент: противостоящие политические организации и общественно-политические движения, политические институты;

- объект - неорганизованные социальные группы - потенциальные агенты их общие интересы и ориентации: субъекты - институты власти и их носители;

- предмет - содержание, направление, методы деятельности власти, структура политических статусов (тип режима);

- цель - программы и политические проекты организаций, средства - политические технологии (формы и методы борьбы);

- результат - реализация политических программ и проектов» [Зеркин 1998: 190].

Исторический и теоретический анализ понятия «политическая борьба» показывает, что оно не идентично понятию конфликта. Оно носит системный характер и требует системного подхода. В качестве деятельности политическая борьба может осуществляться «во имя чего-то», «против кого-то», «вместе с кем-то». Кроме конфликта, оно включает в себя такие элементы, как интерес и власть.

Таким образом, понятие политической борьбы содержит в себе несколько моментов.

Первым моментом политической борьбы становится формулирование и определение политических целей. Этими целями могут быть «борьба за мир», «борьба за жизненное пространство», «борьба за права человека», «борьба за безопасность», «борьба за свободу», «борьба за власть» и т.д. Здесь еще нет противоположного субъекта. Однако есть уже несогласие с существующим положением вещей, со статусом. Интерес фиксирует различие между тем, что есть, и тем, что должно быть в представлении субъекта политической борьбы. Фиксирование недостатка жизненного пространства или безопасности еще не говорит, в каком направлении будет развиваться экспансия. Противник еще не определен, но потенциальная возможность его уже предполагается. Цель, которая определяется в политическом интересе, как правило, не разделяется на несколько частей. Например, борьба за мир в каком-либо регионе предполагает разные представления о мире. В понятии политической платформы в единое иерархизированное целое соединяются разные интересы и цели, средства и методы их достижения. На первом этапе борьба формируется в виде пропаганды определенных целей. В результате пропаганды происходит мобилизация сторонников, в результате которой происходит отделение последних от остального социума.

Вторым моментом политической борьбы является политический конфликт. Конфликт предполагает столкновение интересов различных субъектов с противоположными целями. Конфликт является элементом борьбы, в котором выражается и фиксируется несогласие с противоположной позицией. Фиксация несогласных позиций создает пространство неопределенности, в котором исчезает идентичность субъектов конфликта. Из этой неопределенности вытекает многовариантность и непредсказуемость действий субъектов политической борьбы. В политическом конфликте борьба ведется против противников, которые определены как враги. Борьба становится политической, согласно К. Шмитту, когда значительные группы людей разделяются на «друзей» и «врагов». Конфликт формируется исключительно в публичной сфере. 
«Всякая противоположность - религиозная, моральная, экономическая или этническая - превращается в противоположность политическую, если она достаточно сильна для того, чтобы эффективно разделять людей на группы друзей и врагов» [Шмитт 1992: 45]. Конфликт реализуется в осознанной форме.

Третьим моментом понятия политической борьбы является власть. Политическая борьба как процесс имеет свое начало в формировании интереса политической борьбы, далее следует собственно политический конфликт и достижение в той или иной форме цели политической борьбы, доминирование над противником. Понятие власти отражает достижение определенного единства воль субъектов борьбы. Это может быть победа одного субъекта борьбы и подчинение ему воли другого субъекта. Это может быть согласие в форме компромисса, когда воля одного субъекта поддерживается другими субъектами. Политическая власть исключительно редко строится на насилии. Более приемлемыми формами власти являются господство, основанное на распределении ресурсов, и управление, основанное на распределении компетенций.

Политическую борьбу можно определить как деятельность по реализации интересов в конфликте политических субъектов посредством достижения властных позиций.

По форме политическая борьба разделяется на насильственную и ненасильственную. К насильственным формам политической борьбы относят перевороты, военные действия, революции.

Ненасильственные формы политической борьбы многообразны. К ним относятся такие формы, как забастовки, акции протеста, митинги, выборы, парламентские дебаты, деятельность властей. Соответственно, борьба может быть легитимной и нелегитимной.

Таким образом, понятие политической борьбы в свете его анализа является более широким по отношению к понятию конфликта, а также к формам ее проявления. Политическая борьба представляет собой процесс, который не исчерпывается конфликтом, но включает в себя еще и фазы формирования целей с помощью пропаганды и реализацию их через властный статус.

\section{Список литературы}

Аристотель. 2007. Афинская полития. М.: Флинта; МПСИ. 240 с.

Борщ А.А. 2011. Политическая борьба в современных условиях. М.: Можайский полиграфический комбинат. 192 с.

Борщ А.А. 2013. Политическая борьба в современном мире. - Сравнительная политика. № 3(13). С. 70-73.

Гизо Ф. 2007. История цивилизации в Европе (пер. с франц.). М.: ИД «Территория будущего». $336 \mathrm{c.}$

Егоров А.Б. 2009. Античная демократия и римская политическая система (античные и современные политические теории). - Вестник СПбГУ. Сер. 2. История. № 4. С. 34-47.

Здравомыслов А.Г. 1995. Социология конфликта. М.: Аспект Пресс. 317 с.

Зеркин Д.П. 1998. Основы конфликтологии: курс лекций. Ростов-н/Д: Феникс. $480 \mathrm{c.}$

Зимичев А.М. 1993. Психология политической борьбы. СПб: Санта. 155 с.

Зиммель Г. 1996. Человек как враг. - Избранное. М.: Юрист. Т. 2. С. 500-508.

Кальгина А.А., Белоновский В.Н. 2015. Представительные органы в Древнем Риме и особенности их формирования. - Вестник Московского университета МВД России. № 1. С. 181-184.

Козер Л. А. 2000. Функции социального конфликта (пер. с англ. О. Назаровой; 
под общ. ред. Л.Г. Ионина). М.: Дом интеллектуальной книги; Идея-пресс. 295 c.

Плутарх. 1994. Сравнительные жмизнеописания. В 2 т. Т. І. Перикл. М.: Наука. $706 \mathrm{c}$.

Шмитт К. 1992. Понятие политического. - Вопросы социологии. Т. 1. № 1. C. 37-67.

Энгельс Ф. 1955. Людвиг Фейербах и конец классической немецкой философии. - Маркс К., Энгельс Ф. Сочинения. Т. 21. С. 308-310.

Tilly Ch. 2004. Contention and Democracy in Europe, 1650-2000. New York: Cambridge University Press. 305 p.

ZAIKIN Andrei Anatol'evich, postgraduate student at the North-Western Institute of Management - branch of Russian Presidential Academy of National Economy and Public Administration (RANEPA) (57/43 Sredniy Ave, V.O., St. Petersburg, Russia, 199178; Sptk2011@yandex.ru), Adviser to the Chairman of the Legislative Assembly of St. Petersburg VOLKOV Vitaliy Aleksandrovich, Dr.Sci. (Pol.Sci.), Professor; Professor of Saint-Petersburg State University (7-9 Universitetskaya Emb, St. Petersburg, Russia, 199034; vitv@rambler.ru)

\section{HISTORICAL AND LOGICAL FOUNDATIONS OF THE STRUCTURE OF THE CONCEPT OF POLITICAL STRUGGLE}

Abstract. The article discusses the phenomenon of political struggle in the historical and logical dimension. Since Antiquity, the political fight is developing in various forms, but does not become the subject of a conceptual analysis. The authors are on the point of view that the notion of political struggle is not limited to the notion of political conflict. It includes three necessary elements: the definition of goals and propaganda, the actual conflict, and the achievement of imperious status. The authors propose their own definition of political struggle.

Keywords: political struggle, propaganda, conflict, rhetoric, elections, class struggle, publicity, imperious status 